\title{
Tempo-spatial characteristics of sub-daily temperature trends in mainland China
}

\author{
Yuyu $\operatorname{Ren}^{1} \cdot$ David Parker ${ }^{2} \cdot$ Guoyu Ren $^{1} \cdot$ Robert Dunn ${ }^{2}$
}

Received: 26 October 2014 / Accepted: 22 June 2015 / Published online: 7 July 2015

(C) The Author(s) 2015. This article is published with open access at Springerlink.com

\begin{abstract}
The spatial and temporal pattern of sub-daily temperature change in mainland China was analysed for the period from 1973 to 2011 using a 3-hourly dataset based on 408 stations. The increase in surface air temperature was more significant by night between 1973 and 1992, with the fastest upward trend around local midnight being about $0.27{ }^{\circ} \mathrm{C} /$ decade, while it was more significant by day between 1992 and 2011, with the fastest upward trend being about $0.46{ }^{\circ} \mathrm{C} / \mathrm{decade}$ in mid-late morning. The season with rapid temperature increase also shifted from winter in 1973-1992 (the largest increase happened near midnight in December, $0.75^{\circ} \mathrm{C} /$ decade) to spring in 1992-2011 (the largest increase happened at in the early afternoon in March, $0.82{ }^{\circ} \mathrm{C} /$ decade). The change in the spatial distributions of the sub-daily temperature trends shows that Northeast China warmed more significantly in 1973-1992 than elsewhere, but it cooled in 1992-2011, when Southwest China was the new focus of temperature increase whereas it had previously been cooling. A preliminary analysis of the possible causes implies that changes in solar radiation, cloud cover, aerosols and the observational environments near the stations might have contributed to these observed temperature changes.
\end{abstract}

Keywords Sub-daily temperature $\cdot$ Trend .

Climatic warming $\cdot$ China $\cdot$ Solar radiation $\cdot$ Urbanization

Yuyu Ren

renyuyu@126.com

1 Laboratory for Climate Studies, National Climate Centre, China Meteorological Administration, Beijing,

People's Republic of China

2 Met Office Hadley Centre, Exeter, UK

\section{Introduction}

Recent studies have shown that temperatures at different local times have had different trends. For example, generally minimum daily temperatures worldwide have tended to increase faster than maximum daily temperatures, leading to narrowed Diurnal Temperature Range (DTR) (Karl et al. 1993; Easterling et al. 1997; Dai et al. 1999; Trenberth et al. 2007: IPCC AR4). In recent years, however, some global and regional studies found that trends of DTR in recent decades differed from those observed previously, with some regions like Europe and North America keeping more or less stable and others like mainland China and Africa continuing to decline (Vose et al. 2005; Ren et al. 2005a, b; Wild et al. 2007). China is among the regions of the world which has undergone the largest decrease in DTR over recent decades (Vose et al. 2005; Ren et al. 2012, 2014).

The influential factors leading to the general decrease of DTR and the varied regional trends over the global lands are unclear, though a few studies attributed them to the increasing cloudiness resulting from global climatic warming (e.g. Easterling et al. 1997; Dai et al. 1999; Duan and Wu 2006), the land use and land cover change (e.g. Kalnay and Cai 2003; Zhou et al. 2004, 2010; Jeong et al. 2011), the increasing emission of aerosols in the atmosphere (e.g. Wang et al. 2012), and the large urbanization effect on minimum temperature at night (e.g. Kalnay and Cai 2003; Zhou and Ren 2009; Ren and Zhou 2014). Zhou and Ren (2009) and Ren and Zhou (2014) indicated that urbanization effects could explain almost all of the decreasing trends of DTR for the past five decades for the national reference climate stations and basic meteorological stations in North China.

The previous studies covering China usually used daily or monthly mean temperature data from national reference 
climate stations and national basic meteorological stations in mainland China. The detailed sub-daily structure of temperature change and its relationship with change in DTR remained unknown owing to the lower time resolution of the data used. In this paper, we used a dataset of 3-hourly temperature to analyse the diurnal cycle of temperature change over China. The results enable us to surmise the likely forcings underlying sub-daily temperature change in a sub-continental region.

\section{Data and method}

We used sub-daily temperature records for China for 19732011 from the HadISD (Hadley Centre Integrated Surface Database) dataset (version HadISD1.0.0.2011f) developed by Dunn et al. (2012). HadISD is an automatically qualitycontrolled synoptic resolution multi-variable dataset and includes 418 Chinese stations (Fig. 1). The data compiled for each station provide 8-times daily observed records at the hours listed in Table 1 in UTC and corresponding Beijing Time (BJT).

HadISD data have been quality controlled (Dunn et al. 2012) and a homogeneity assessment has been made (Dunn et al. 2014), but without applying homogeneity adjustments. The inhomogeneity introduced by nonclimatic shifts (station moves, instrument changes, etc.) can adversely affect the analysis of climate change. For example, if a station moves from mountain top to valley, the temperature is expected to increase significantly, in addition to any change of temperature at a given site. In this paper, the temperature change is the object

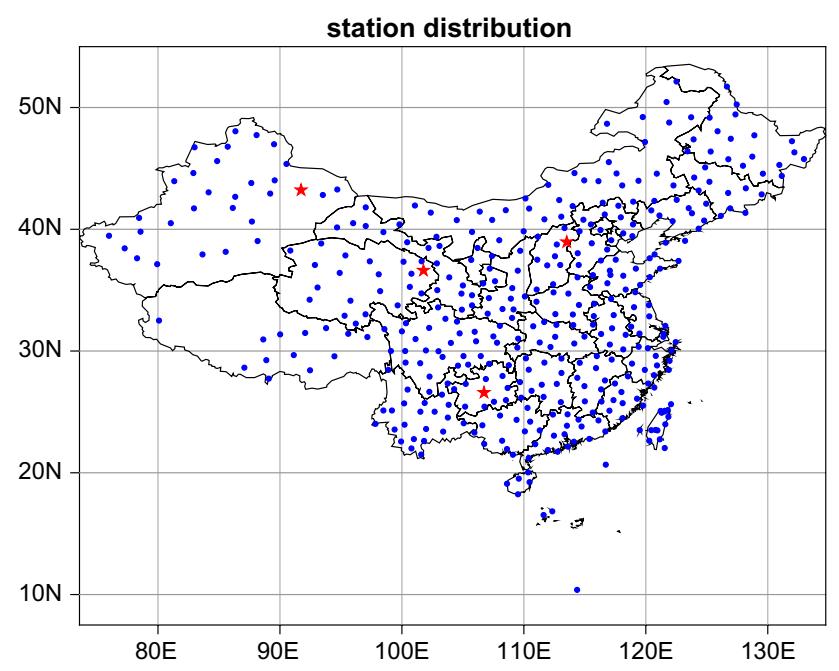

Fig. 1 The distribution of HadISD stations in China (Red stars are the four stations relocated) of analysis, so we used outlying linear trends to detect homogeneity. On comparing the linear trends of each station, we found several stations with outlying values (below the 1st or above the 99th percentile of temperature trends of all stations). By examining the temperature series of these stations, we found some abrupt changes which probably indicated inhomogeneity in the records. For example, Wutai Shan Station (ID 53588) experienced an abrupt warming which exceeds the range of natural climate variability and regional warming, and has no analogue in neighbouring stations (Fig. 2). Station historical information shows that Wutai Shan Station was relocated from the Zhongtai Peak of the Wutaishan Mountains to the nearly $700 \mathrm{~m}$ lower Muyushan Peak in January 1998. That is likely to be the main reason for the breakpoint in the temperature series. By comparing the abnormal temperature breakpoints and the station historical information, we were able to identify the most obvious inhomogeneity problems in four stations (Fig. 2). They are Wutaishan (53588), Guiyang (57816), Shisanjianfang (51495) and Xining (52866). If retained, the data from those four stations would have introduced spurious, nonclimatic trends to the results. So the data of the four stations were excluded from the analysis.

To reduce the biases caused by uneven station density or temporal variations in data coverage, the Climate Anomaly Method (CAM, Jones et al. 2012) was employed to interpolate station data to a regular grid. All stations included in the analysis were required to have at least 20 years of records during the 1981-2010 reference period. Monthly averages of each observing hour were calculated when there were least 23 valid data at that hour in the month. Annual averages were then calculated using all the 12 monthly mean values within a year. Monthly normals for each station for 1981-2010 were calculated for each observing time and used to calculate anomalies for that station for each individual month and observing time. Each station was assigned to a $5^{\circ} \times 5^{\circ}$ latitude-longitude grid box to get a more regular and complete spatial cover; then grid box anomaly values were calculated by simple averaging of anomaly values for all available stations within each grid box for each month and observing time for 1973-2011. The country average anomaly is the weighted (using the cosine of the mid-grid-box latitude) average of all available grid box anomalies in a given month. The observations were made every $3 \mathrm{~h}$ (Table 1) so, to sample approximately the same local solar time country-wide when calculating the country average temperature anomaly, we combined observations at a given time (e.g. 8 BJT) at stations east of $97.5^{\circ} \mathrm{E}$ with observations $3 \mathrm{~h}$ later (e.g. $11 \mathrm{BJT}$ ) at stations west of $97.5^{\circ} \mathrm{E}$. We denote the combined time Approximate Local Solar Time (ALST). 

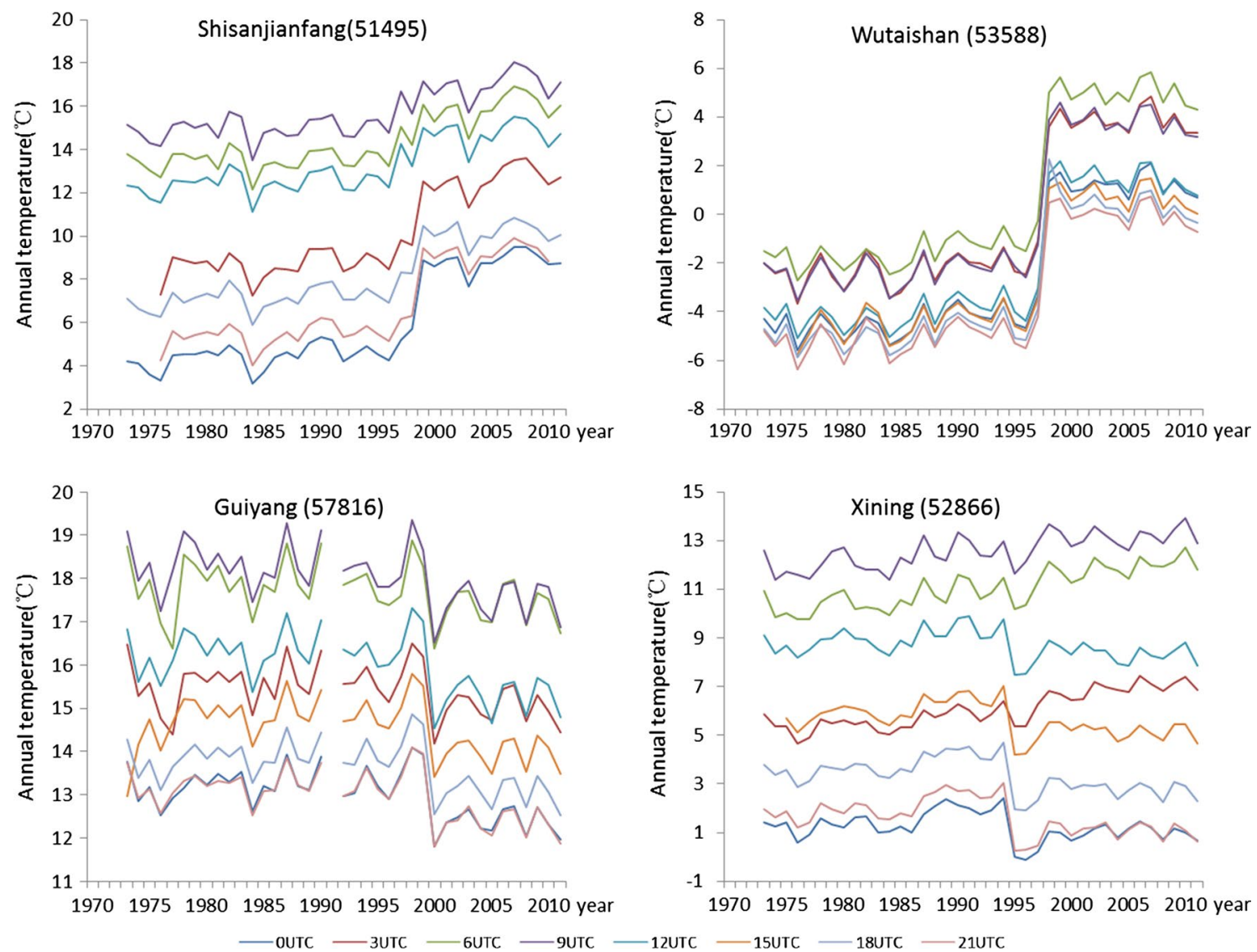

Fig. 2 Temperature series showing the discontinuities induced by relocations for four stations of mainland China

Six stations had insufficient data during the reference period, so with the inhomogeneous stations we excluded 10 altogether, retaining 408 stations to calculate the China average temperature series.

The ordinary least squares method was employed to estimate linear trend coefficients and $t$ tests were used to estimate statistical significance.

\section{Results}

\subsection{Temperature changes at different hours}

For the period 1973-2011, the temperature changes at 8, 11 and 14 ALST were greater than those by night (Fig. 3). This result differs from the prevalent reduction of DTR documented in the Introduction, suggesting that the

Table 1 The observing hours in UTC and corresponding BJT

\begin{tabular}{lllllllll}
\hline UTC & 00 & 03 & 06 & 09 & 12 & 15 & 18 & 21 \\
BJT & 08 & 11 & 14 & 17 & 20 & 23 & 02 & 05 \\
\hline
\end{tabular}

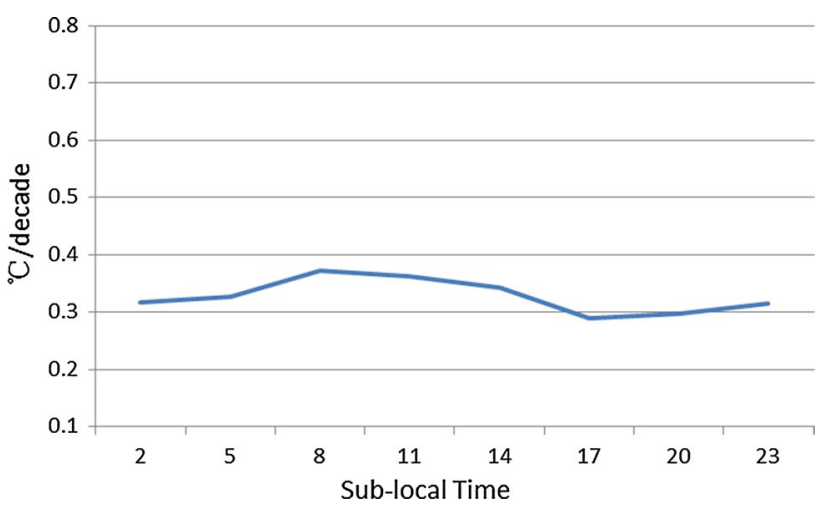

Fig. 3 Country-averaged hourly mean temperature trends for 19732011 at different hours (ALST) $\left({ }^{\circ} \mathrm{C} /\right.$ decade $)$

forcings of surface temperature trends may have changed in recent years. To analyse the historical changes of temperature trends as a function of observing time, we calculated the hourly mean temperature trends for five different 20-year periods: 1973-1992 (Fig. 4a), 1978-1997 (Fig. 4b), 1983-2002 (Fig. 4c), 1988-2007 (Fig. 4d) and 1992-2011 (Fig. 4e). 

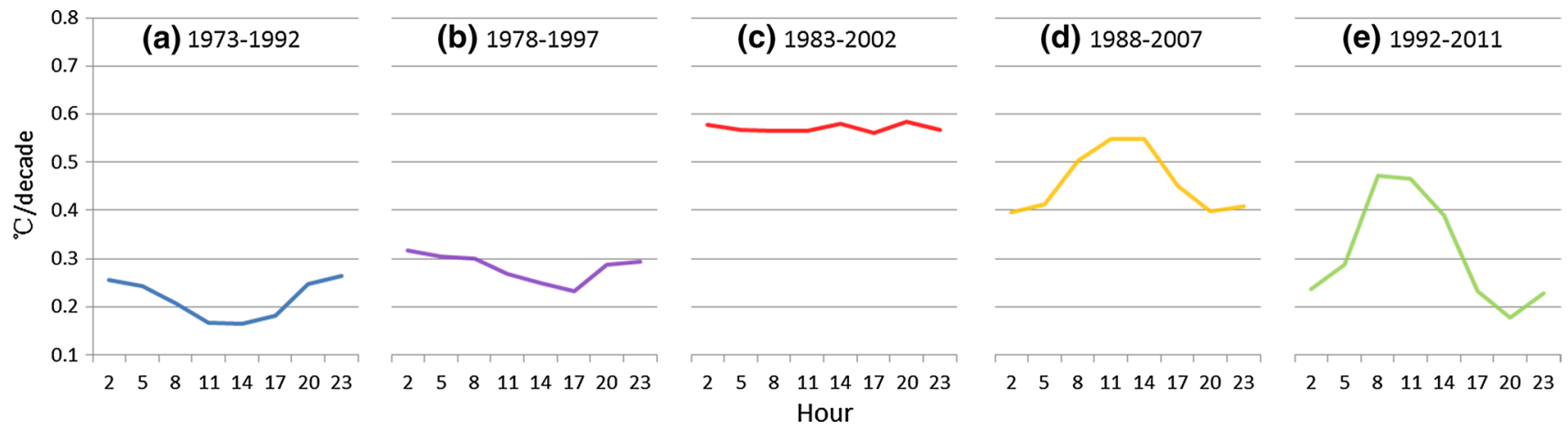

Fig. 4 Country-averaged hourly mean temperature trends for five 20-year periods at different hours (ALST) $\left({ }^{\circ} \mathrm{C} /\right.$ decade)

Figure 4a shows that the temperature increases at 20, 23, 02 and 05 ALST were faster than at other hours during 1973-1992. This is consistent with previous studies indicating minimum temperature increasing faster than maximum, as cited in the Introduction, because the minimum temperature generally occurs before sunrise or about 04-08 local solar time, and the maximum temperature in early afternoon or about 13-17 local solar time (Figs. 5, 6, 7, 8, 9). For 1978-1997, however, the differences between temperature trends at different hours were narrower: the range reduced from 0.10 to $0.08{ }^{\circ} \mathrm{C} /$ decade. As time progressed, the daytime temperature especially near midday increased more and more quickly compared with nighttime temperature. During the period 19832002, both nighttime and daytime temperature trends reached the highest values of the five 20 -year periods, with the daytime temperature trends increasing to levels similar to those at night. The minimum daytime temperature increased at $0.56{ }^{\circ} \mathrm{C} /$ decade and the maximum nighttime temperature increased at $0.58{ }^{\circ} \mathrm{C} /$ decade. This period included the period of most rapid global warming, in which China shared. It also coincided with a transition from a night maximum to a day maximum in temperature trends over China, so there was no diurnal cycle in the trends. Around the middle of this period, solar dimming ceased over China (see Fig. 10 and the Discussion section below), allowing enhanced warming especially by day. After the period 1983-2002, there was a reversal of the diurnal pattern of temperature trends, with the daytime (11 and 14 ALST) trends remaining at relatively high levels (both at $0.55{ }^{\circ} \mathrm{C} /$ decade), but the nighttime trends dropping markedly to their earliest 20-year levels, for example, the trends at 20 ALST decreased from 0.58 to $0.40{ }^{\circ} \mathrm{C} / \mathrm{dec}$ ade. The divergence of trends between different hours has become larger and larger. The most recent 20-year temperature trends at night have been around $0.25^{\circ} \mathrm{C} / \mathrm{dec}$ ade, while all the daytime trends have exceeded $0.30{ }^{\circ} \mathrm{C} / \mathrm{dec}$ ade and the largest two trends, at 8



Fig. 5 The temperature trends of China ordered by the differences of observing hours from 12 ALST for periods 1973-1992 and 19922011

and 11 ALST, exceeded $0.46{ }^{\circ} \mathrm{C} /$ decade, more than double the trends at 20 and 23 ALST.

The trends for 1972-1992 (1992-2011) increase slightly (decline strongly) in proportion to the (absolute) time offset from 12 ALST (Fig. 5). During 1973-1992, the temperature at $11 \mathrm{ALST}$ increased at $0.17{ }^{\circ} \mathrm{C} / \mathrm{decade}$, while at 02 and 23 ALST the trends were 0.26 and $0.27{ }^{\circ} \mathrm{C} / \mathrm{dec}$ ade respectively. But during 1992-2011, trends exceeded $0.46{ }^{\circ} \mathrm{C} /$ decade at 08 and 11 ALST but were $<0.20^{\circ} \mathrm{C} / \mathrm{dec}-$ ade at 20 ALST.

We analysed calendar monthly temperature data in the same way. To smooth the high-frequency variations arising from the short analysis period (20 years), we calculated the average of the first five 20-year linear trends, from 1973-1992 to 1977-1996 (Fig. 6 left). In the earlier years, the fastest monthly temperature increase happened in December, and the monthly mean temperature linear trend at $23 \mathrm{ALST}$ was $0.75^{\circ} \mathrm{C} / \mathrm{dec}$ de, while the average trend was $-0.01{ }^{\circ} \mathrm{C} /$ decade at $17 \mathrm{ALST}$ in October. The months with the strongest warming trends were January, February and December, followed by November. The 
Fig. 6 The hour (ALST) month profile of averages of moving temperature trends $\left({ }^{\circ} \mathrm{C} /\right.$ decade) of China for periods 1973-1992 through 1977-1996 (a) and 1988-2007 through 1992-2011 (b) (a)

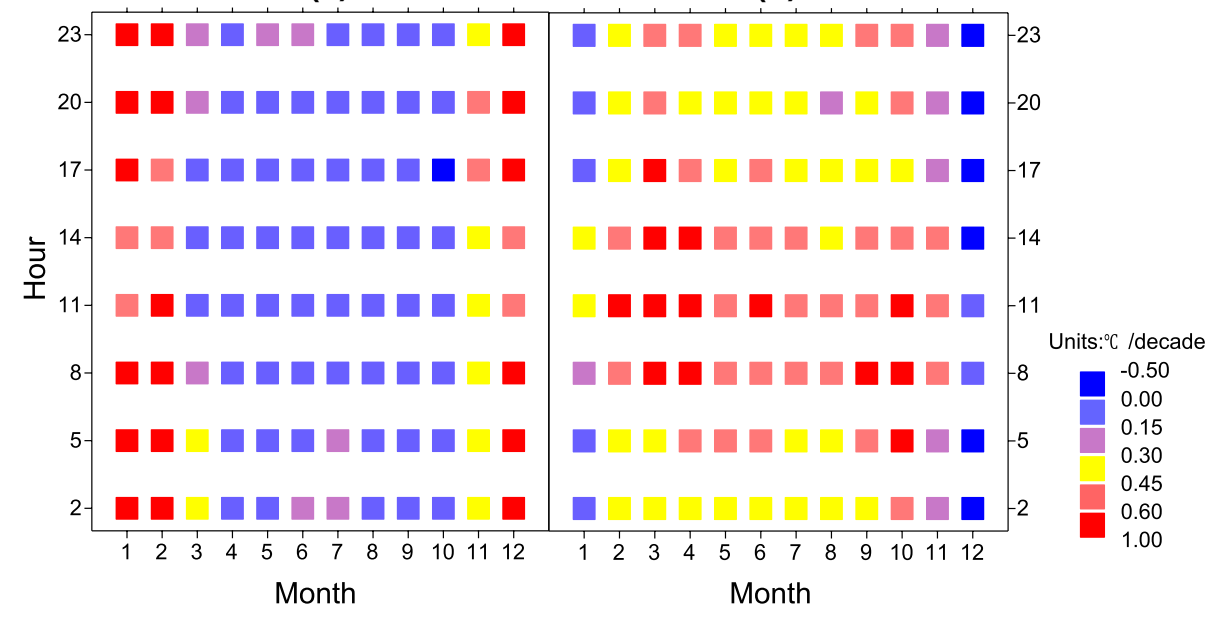

temperature increases at night in the three winter months are more significant than those by day, and almost sinusoidal with the peak at 23 or 02 ALST and the trough at 14 or 17 ALST. Accordingly, in accordance with prior published research on maximum and minimum temperatures, we conclude that the temperature trend was greater by night.

For the recent years, from 1988-2007 to 1992-2011 (Fig. 6 right), the temperature trends in China were greater in spring and autumn than in winter and greater by day than by night. The fastest monthly temperature increase was in March, with a linear trend of $0.82{ }^{\circ} \mathrm{C} /$ decade at 14 ALST, while a large decrease in temperature was evident in early winter, with the average trend at 20 ALST in December being $-0.22{ }^{\circ} \mathrm{C} /$ decade. The first two largest linear trends (exceeding $0.80{ }^{\circ} \mathrm{C} /$ decade) happened at 14 and 11 ALST in March, followed by trends at 08 and 17 ALST in March, and 08 ALST in October. The temperature increases by night in March are distinctly less than those by day, with the lowest values at $05 \operatorname{ALST}\left(0.41{ }^{\circ} \mathrm{C} /\right.$ decade) and 02 $\operatorname{ALST}\left(0.44^{\circ} \mathrm{C} /\right.$ decade $)$.

Comparing the two epochs, the linear trend at 23 and 20 ALST in December fell respectively from 0.75 to $0.72{ }^{\circ} \mathrm{C} /$ decade in the earlier years (trends in the first three 20-year periods exceeded the 0.05 significance level) to -0.19 and $-0.22{ }^{\circ} \mathrm{C} /$ decade in the recent years. In January, all trends at night declined by more than $0.65{ }^{\circ} \mathrm{C} /$ decade. At the same time, the temperature increases in other months accelerated. Trends at 11 and 14 ALST in March increased respectively from 0.04 and $0.12{ }^{\circ} \mathrm{C} /$ decade to 0.81 and $0.82{ }^{\circ} \mathrm{C} /$ decade. There was almost a reversal of the diurnal pattern of trends between the early epoch (early 1970s through early 1990s) and the late epoch (late 1980s through early 2010s).

\subsection{The distribution of sub-daily temperature trends}

To investigate the spatial distribution of temperature changes, temperature anomalies in $2.5^{\circ} \times 2.5^{\circ}$ latitudelongitude grids were calculated by simply averaging all available station anomalies within the grids and then the temperature trends in the grids with at least 15 valid annual records were calculated for 1973-1992 and 19932011 separately. January 1, 1993 was chosen as the boundary so as to have two approximately equal-length analysis periods (Fig. 7).

Figure 7 shows clear regional patterns for 1973-1992. The distributions of the annual temperature trends suggest that the area of strongest temperature increases was north of about $40^{\circ} \mathrm{N}$, stretching from north-east to north-west China: the increases by night often exceeded the $95 \%$ significance level and were greater than those by day. On the other hand, the Sichuan Basin $\left(30.5 \pm 2^{\circ} \mathrm{N}, 105.5 \pm 2^{\circ} \mathrm{E}\right)$ and parts of central China experienced annual cooling trends.

The annual temperature trends for 1992-2011 generally exceed those for 1973-1992 and have very different spatial and temporal distributions. Warming trends covered most of China at 08BJT and 11BJT during 1992-2011 with the strongest and most significant (at $95 \%$ level) increase in central-western China. The weakest warming, with isolated areas of cooling, occurred in Northeast China and parts of North China, a region which experienced the strongest warming during 19731992. For 14BJT and 17BJT, the country is divided into two regions by a straight line from $\left(50^{\circ} \mathrm{N} 90^{\circ} \mathrm{E}\right)$ through $\left(30^{\circ} \mathrm{N}, 110^{\circ} \mathrm{E}\right)$ to $\left(30^{\circ} \mathrm{N}, 120^{\circ} \mathrm{E}\right)$. In the south-western region, there was strong warming, but the north-eastern region was dominated by cooling. At 20BJT, 23BJT, 02BJT, and 05BJT which experienced the strongest 
Fig. 7 The linear trends of hourly mean temperature at different BJT hours in 1973-1992 (left) and 1992-2011(right) (Black boxes indicate trends statistically significant at the $95 \%$ level)
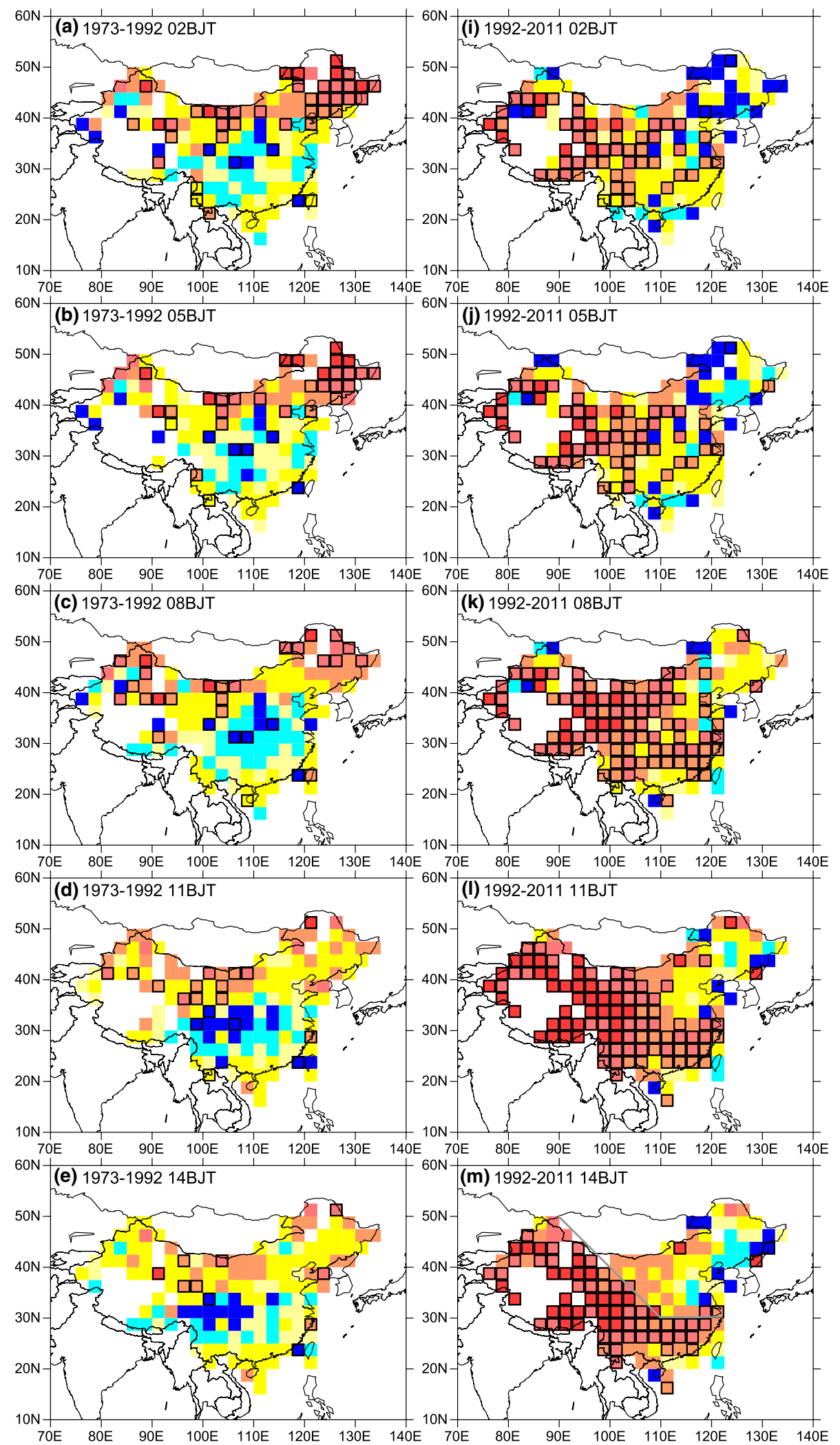

warming trends during 1973-1992, the area with significant increase shrunk and north-east China along with a few grids elsewhere showed relatively large cooling trends in 1992-2011. The area with warming trends was the smallest at 20BJT with a gradual increase to 05BJT and then a greater increase to $08 \mathrm{BJT}$ and 11BJT. 
Fig. 7 continued


-1 to $-0.01 \quad-0.01$ to $0 \quad 0$ to 0.01

0.05 to $0.08 \quad 0.08$ to 1.2

1.2 to 2 (units: ${ }^{\circ} \mathrm{C} / \mathrm{dec}$ ade)

Although the distribution of rapid warming trends changed markedly, the grids with statistically significant warming far outnumber those with statistically significant cooling, and most of the warming grids were statistically significant, especially for 1992-2011.

\section{Discussion}

The findings presented above are importantly different from previous findings for China for the temperature change of recent decades. These generally showed more significant warming at night than by day in terms of larger changes in minimum temperature than in maximum temperature (Zhai and Pan 2003; Qian and Lin 2004; Zhou and Ren 2011; You et al. 2012), leading to large decreases in DTR, cold nights frequency and frost days (Yan et al. 2002; Gong and Han 2004; Alexander et al. 2006; Choi et al. 2009; Zhang et al. $2011 \mathrm{~b}$ ), and more significant warming in winter over northern China (Ren et al. 2005a, b, 2012; Ding et al. 2006).
Our analysis indicates, however, that the temperature change patterns over mainland China since the 1990s have been substantially different, with a marked slowdown of nighttime warming and an accelerated increase of daytime temperature. The seasonality and regionality of the warming have also changed, with December and January of wintertime witnessing a cooling trend in the country on a whole during the last two decades, and the previously rapid-warming Northeast China now undergoing an annual cooling trend.

We analysed the change in monthly surface air temperature trends using the Twentieth Century Reanalysis (20CR: Compo et al. 2011). The strong decline in winter and moderate increase in summer over China are also evident in the changes of temperature trends between 1973-1992 and 1992-2011 in the reanalysis data (Fig. 8). The largest declines of winter temperatures were in the Siberian region of Russia, Northeast China and south-eastern United States, and the most obvious increase of summer temperature trends appeared in the United States, North Atlantic, 



Fig. 8 The summer and winter mean temperature trends in the Twentieth Century Reanalysis for 1973-1992 (above) and 1992-2011 (below)
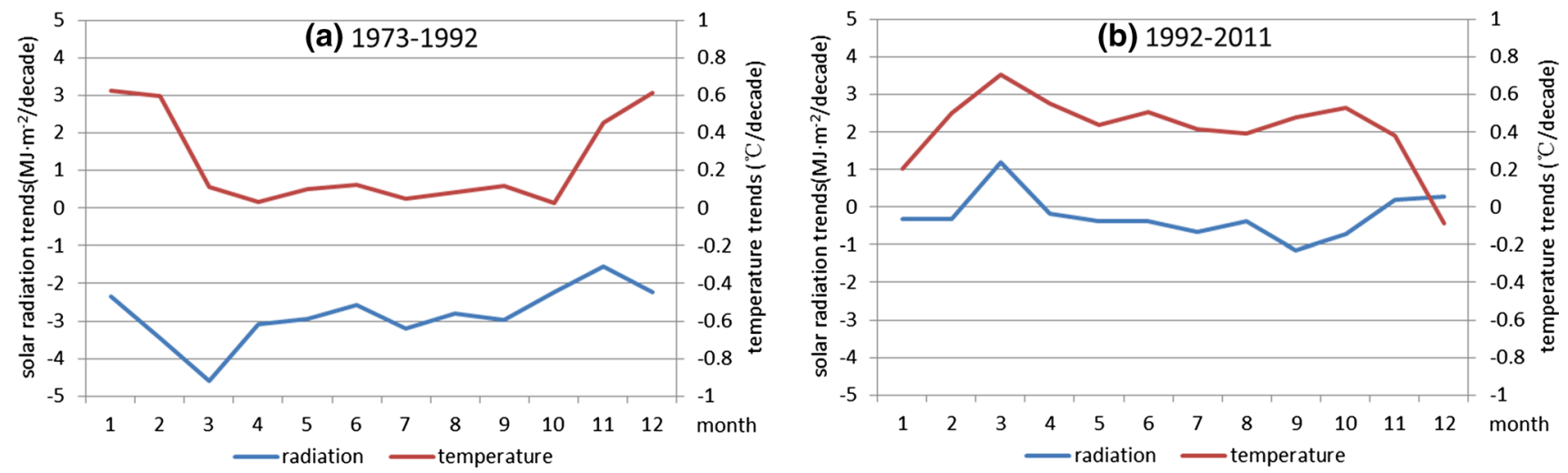

Fig. 9 Monthly solar radiation and daytime temperature (11-20 ALST) trends in mainland China

Greenland and central Asia. 20CR is driven by surface pressure data, ocean surface temperatures, and atmospheric greenhouse gas concentrations, but it does not include cloud or anthropogenic aerosol data, and its surface temperature patterns strongly reflect atmospheric circulation changes. So Fig. 8 suggests that atmospheric circulation changes have had a major role in the changes in temperature trends over China, especially in winter. But our finding that the trends pattern changed differently at different observing times between 1973-1992 and 1992-2011, also suggests that further factors have caused diurnal modulation of temperature trends in mainland China.

These factors may include solar radiation receipt at the land surface and artificial heat emission absorbed by the near-surface air. Modified energy exchange between air and land due to land use and land cover change is also important. In addition, inter-decadal snow cover and ocean temperature variations may affect the winter and summer 
Fig. 10 Annual mean sunshine percentage anomaly from 1973 to 2011 in mainland China (Unit \%)

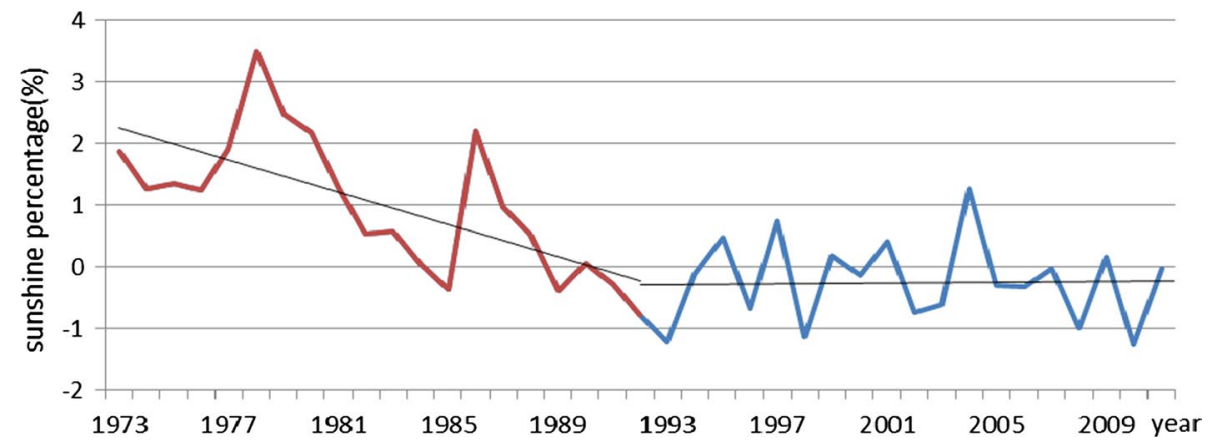

temperature changes in China through the monsoonal atmospheric circulations.

The downward shortwave solar radiation has a major and direct influence on daytime temperature. Many studies have found that total solar radiation received at the land surface has changed worldwide, and global "dimming" from the 1960 s to the 1980 s has been followed by global "brightening" since the beginning of the 1990s (e.g. Gilgen et al. 1998; Luo et al. 2000, 2001; Stanhill and Cohen 2001; Liepert 2002; Forgan et al. 2005; Wild et al. 2005; Wild 2009). In mainland China, the shift from decline to stability or even a recovery in terms of surface solar radiation and sunshine duration also occurred in the early $1990 \mathrm{~s}$ (Ren et al. 2005a; Che et al. 2005; Qian et al. 2007; Shi et al. 2008, 2009; Norris and Wild 2009). The long-term change in surface solar radiation over mainland China was attributed to global and regional changes of aerosol properties in the early 1990s (Qian et al. 2007). However Shi et al. (2008) also noted changes in Chinese radiation instrumentation in the early 1990s, and Zhang et al. (2012) in a modelling study derive overall negative direct radiative forcing, and resultant coolness, over eastern Asia given recent (after 2000) anthropogenic aerosol emissions.

We also used our method to calculate China average temperature, to obtain a China average solar radiation series, based on 93 stations. The monthly solar radiation trends in the two periods are compared with the temperature trends by day (Fig. 9). Between 1973-1992 and 19922011, the solar radiation trends became less negative and the daytime temperature trends increased (given ongoing greenhouse gas forcing) except in the winter when atmospheric circulation changes brought colder air in the later period (Fig. 8).

So we surmise that surface solar radiation change has to some extent affected temperature trends by day and in the warm seasons, leading to a subdued daytime and warm season warming relative to the nighttime and cold season warming before the early 1990s, and a reversal of the diurnal and seasonal temperature trends after that. The time of the shift in diurnal temperature trends approximately coincides with the transition from regional "dimming" to "brightening". We support these suggestions as follows.

Higher sunshine percentage is an indicator of clearer sky, less cloud cover and less aerosol, so more solar radiation can reach the surface and more long-wave radiation can escape to space. Therefore sunshine percentage can approximate the combined effect of cloud cover and aerosols, and can be adopted to linearly simulate solar radiation in China (Chen et al. 2004; Zhou et al. 2005; Wu et al. 2009a, b; Deng et al. 2013). We therefore calculated a time series of China average sunshine percentage using the same averaging-method as for temperature and solar radiation (Fig. 10).

An obvious turning point in the early 1990 s can be seen in Fig. 10. There is a sharp downward trend at $-1.3 \% /$ decade before 1992 and a flattening after 1992 (0.04\%/ decade), consistent with the solar radiation trends in Fig. 9. It is likely that the overall decline of sunshine percentage caused a slower temperature increase by day than by night for the period as a whole. The influence would be more important for the global dimming period due to the significant decrease of short-wave radiation reaching the surface and increases in the upward long-wave energy absorbed by the near-surface air, reducing temperature increase by day and enhancing temperature increase by night.

Both cloud cover and aerosols increase the downward long wave energy flux by night and decrease the downward shortwave energy flux by day. The long-term change of aerosols, however, may have exerted a bigger influence, because total cloud cover decreased over mainland China at $-0.6 \%$ per decade in 1971-1989 and -0.8\% per decade in 1990-2002 (Norris and Wild 2009), and so might not be a major factor for the observed change in diurnal temperature trends in the country on a whole. With regard to aerosols, scattering sulphur and absorbing black carbon aerosols all tended to increase until about the late 1980s (Stern 2006; Streets et al. 2006). Likewise aerosol optical depth over China showed an increase, but this became slower after 1985 (Luo et al. 2001; Qin et al. 2010; Zhang et al. 2011c). 
Artificial heat emission and land cover change near the meteorological stations are mainly the results of city expansion or urbanization. Many studies suggested that urbanization has significantly affected surface air temperature change through modifying land cover, air composition and the anthropogenic heat release (Ren et al. 2008, Ren and Zhou 2014; Zhou and Ren 2009; Hu et al. 2010; Zhang et al. 2010; Parker 2010; Stewart 2011; Li and Zhao 2012; Wang et al. 2012). Zhou and Ren (2009), Zhang et al. (2011a) and Ren and Zhou (2014) found that the single-site and regional-scale urbanization in mainland China had more significantly increased the minimum temperature trends and significantly narrowed the DTR during the past five decades. Ren and Zhou (2014) also reported an urbanization effect on long-term trends of daily maximum temperature and warm (cold) day frequencies based on Tmax in especially southern China during 1961-2008, and tentatively related it to the increasing urban heat island (UHI) intensity near the observational sites due to the wide use of air-conditioning during daytime in summer over the last two decades. This may have played a role in the shift of seasonality of monthly temperature trends from larger warming in winter to increased warming in summer.

The influences of the decadal variability of large-scale ocean-atmospheric modes such as PDO, ENSO and AMO might also have been important as evidenced in Fig. 8 and previous research (Kosaka and Xie 2013; Meehl et al. 2014). In China, Kang et al. (2006) found the inter-decadal variation of winter temperature was associated with the change of hemispheric scale atmospheric circulation structure. Zuo et al. (2014), whose findings included a decline in the number of days within extreme cold events in winter in China up to 1987 followed by an increase up to 2012, described relationships between China winter extreme temperature events and hemispheric-scale atmospheric circulation and ocean thermal conditions. Other research also found an inter-decadal shift of the summer climate in China in the late 1980s and relationships between summer monsoon change over China and Eurasian snow cover, Arctic sea ice, and the temperatures of the Atlantic, tropical Pacific and Indian oceans (Zhang et al. 2008, 2013; Wu and Zhang 2007; Wu et al. 2009a, b). The change of seasonal temperature increase pattern is the result of atmosphereocean and atmosphere-land inter-action (Kang et al. 2006; Zuo et al. 2014).

\section{Conclusions}

We investigated the sub-daily temperature trends and their changes with time over China during 1973-2011. The following conclusions can be drawn from the analysis:
1. The increases of daytime temperature were more rapid than those of nighttime temperature during 1973-2011 in the country as a whole, with the positive trends at 08 ALST being the largest.

2. There was a major difference of diurnal warming between the periods 1973-1992 and 1992-2011, with the former characterized by larger warming at night in winter, and the latter by rapidly enhancing warming by day in the warm seasons. The hours of peak warming changed from 23 or 02 ALST during 1973-1992 to 08 or 11 ALST during 1992-2011.

3. The spatial patterns of the sub-daily temperature trends have also changed. In 1973-1992, Northeast China witnessed the largest nighttime warming, but during 1992-2011 it experienced evening and nighttime cooling, and southwestern parts of the country underwent daytime warming.

4. It is likely that the changes of diurnal temperature trends in the time period analysed were caused by a combination of factors including total surface solar radiation (influenced by aerosol optical depth) and urbanization near the observational stations, superimposed on the influence of large-scale atmospheric circulation. All these need further investigation.

Acknowledgments D. Parker and R. Dunn were supported by the Joint DECC/Defra Met Office Hadley Centre Climate Programme (GA01101), UK. G.Y. Ren and Y.Y. Ren are supported by the Ministry of Science and Technology of China (Grand No. GYHY201206012). Twentieth Century Reanalysis V2 data were provided by the NOAA/ OAR/ESRL PSD, Boulder, Colorado, USA, from their Web site at http://www.esrl.noaa.gov/psd/. Support for the Twentieth Century Reanalysis Project dataset is provided by the US Department of Energy, Office of Science Innovative and Novel Computational Impact on Theory and Experiment (DOE INCITE) program, and Office of Biological and Environmental Research (BER), and by the National Oceanic and Atmospheric Administration Climate Program Office.

Open Access This article is distributed under the terms of the Creative Commons Attribution 4.0 International License (http://creativecommons.org/licenses/by/4.0/), which permits unrestricted use, distribution, and reproduction in any medium, provided you give appropriate credit to the original author(s) and the source, provide a link to the Creative Commons license, and indicate if changes were made.

\section{References}

Alexander LV, Zhang X, Peterson TC et al (2006) Global observed changes in daily climate extremes of temperature and precipitation. J Geophys Res 111(3):D05109

Che HZ, Shi GY, Zhang XY, Arimoto R, Zhao XuL, Wang B, Chen ZH (2005) Analysis of 40 years of solar radiation JQ data from China, 1961-2000. Geophys Res Lett 32:L06803. doi:10.1029/2 004GL022322 
Chen RS, Ersi K, Yang JP, Lu SH, Zhao WZ (2004) Validation of five global radiation models with measured daily data in China. Energy Convers Manag 45(11-12):1759-1769

Choi G, Collins D, Ren GY, Trewin B, Baldi M, Fukuda Y, Afzaal M, Pianmana T, Gomboluudev P, Huong PTT, Lias N, Kwon WT, Boo KO, Cha YM, Zhou Y (2009) Changes in means and extreme events of temperature and precipitation in the AsiaPacific Network region, 1955-2007. Int J Climatol 29:19061925. doi:10.1002/joc1979

Compo GP, Whitaker JS, Sardeshmukh PD, Matsui N, Allan RJ, Yin X, Gleason BE, Vose RS, Rutledge G, Bessemoulin P, Brönnimann S, Brunet M, Crouthamel RI, Grant AN, Groisman PY, Jones PD, Kruk M, Kruger AC, Marshall GJ, Maugeri M, Mok HY, Nordli $\varnothing$, Ross TF, Trigo RM, Wang XL, Woodruff SD, Worley SJ (2011) The twentieth century reanalysis project. Q J R Meteorol Soc 137:1-28. doi:10.1002/qj776

Dai A, Trenberth KE, Karl TR (1999) Effects of clouds, soil moisture, precipitation and water vapor on diurnal temperature range. J Clim 12:2451-2473. doi:10.1175/1520-0442(1999)012<2451:EOCSM $\mathrm{P}>20 \mathrm{CO} ; 2$

Deng YJ, Qiu XF, Zeng Y, Shi GP (2013) Comparison of horizontal global solar radiation models. J Meteorol Sci 33(4):371-377. doi :10.3969/2012jms.0124

Ding YH, Ren GY, Shi GY et al (2006) National assessment report of climate change (I): climate change in China and its future trend. Adv Clim Chang Res 2(1):3-8 (in Chinese)

Duan A, Wu G (2006) Change of cloud amount and the climate warming on the Tibetan Plateau. Geophys Res Lett 33:L22704. doi:10 .1029/2006GL027946

Dunn RJH, Willett KM, Thorne PW, Woolley EV, Durre I, Dai A, Parker DE, Vose RS (2012) HadISD: a quality-controlled global synoptic report database for selected variables at long-term stations from 1973-2011. Clim Past 8:1649-1679. doi:10.5194/ cp-8-1649-2012

Dunn RJH, Willett KM, Morice CP, Parker DE (2014) Pairwise homogeneity assessment of HadISD. Clim Past 10:1501-1522. doi:10.5194/cp-10-1501-2014

Easterling DR et al (1997) Maximum and minimum temperature trends for the globe. Science 277:364-367

Forgan B, Kallis A, Russak V, Tsvetkov A (2005) From dimming to brightening: decadal changes in solar radiation at Earth's surface. Science 308:847-850. doi:10.1126/science.1103215

Gilgen H, Wild M, Ohmura A (1998) Means and trends of short-wave irradiance at the surface estimated from global energy balance archive data. J Clim 11:2042-2061

Gong DY, Han H (2004) Extreme climate events in northern China over the last 50 years. Acta Geophys Sin 59(2):230-238 (in Chinese)

Hu Y, Dong W, He Y (2010) Impact of land surface forcings on mean and extreme temperature in eastern China. J Geophys Res 115:D19117. doi:10.1029/2009JD013368

Jeong SJ, Ho CH, Park TW, Kim J, Levis S (2011) Impact of vegetation feedback on the temperature and its diurnal range over the Northern Hemisphere during summer in a $2 \times \mathrm{CO} 2$ climate. Clim Dyn 37(3-4):821-833

Jones PD, Lister DH, Osborn TJ, Harpham C, Salmon M, Morice CP (2012) Hemispheric and large-scale land surface air temperature variations: an extensive revision and an update to 2010 . J Geophys Res 117:D05127. doi:10.1029/2011JD017139

Kalnay E, Cai M (2003) Impact of urbanization and land-use change on climate. Nature 423:528-531

Kang LH, Chen W, Wei K (2006) The interdecadal variation of winter temperature in China and its relation to the anomalies in atmospheric general circulation. Clim Environ Res 11(3):330-339. doi:10.3878/j.issn.1006-9585.2006.03.09 (in Chinese)
Karl TR, Knight RW, Gallo KP, Peterson TC, Jones PD, Kukla G, Plummer N, Razuvayev V, Lindseay J, Charlson RJ (1993) A new perspective on recent global warming: asymmetric trends of daily maximum and minimum temperature. Bull Am Meteorol Soc 74(6): 1007-1023

Kosaka Y, Xie SP (2013) Recent global-warming hiatus tied to equatorial Pacific surface cooling. Nature. doi:10.1038/ nature 12534

Li Y, Zhao X (2012) An empirical study of the impact of human activity on long-term temperature change in China: a perspective from energy consumption. J Geophys Res 117:D17117. doi:10. 1029/2012JD018132

Liepert BG (2002) Observed reductions of surface solar radiation at sites in the United States and worldwide from 1961 to 1990. Geophys Res Lett 29(10):1421. doi:10.1029/200 2GL014910

Luo YF, Lu D, He Q, Wang F (2000) An analysis of direct solar radiation, visibility and aerosol optical depth in south China coastal area. J Clim Environ Res 5(1):36-44. doi:10.3878/jissn1006958520000107 (in Chinese)

Luo Y, Lu D, Zhou X, Li W, He Q (2001) Characteristics of the spatial distribution and yearly variation of aerosol optical depth over China in last 30 years. J Geophys Res 106:14501-14513. doi:10. 1029/2001JD900030

Meehl GA et al (2014) Decadal climate prediction: an update from the trenches. Bull Am Meteorol Soc 95:243-267

Norris JR, Wild M (2009) Trends in aerosol radiative effects over China and Japan inferred from observed cloud cover, solar "dimming", and solar "brightening". J Geophys Res 114:D00-D15. doi:10.1029/2008JD011378

Parker DE (2010) Urban heat island effects on estimates of observed climate change. Wiley Interdiscip Rev Clim Change 1:123-133. doi: $10.1002 / \mathrm{wcc} 021$

Qian WH, Lin X (2004) Regional trends in recent temperature indices in China. Clim Res 27(3):119-134. doi:10.3354/cr027119

Qian Y, Wang W, Leung LR, Kaiser DP (2007) Variability of solar radiation under cloud-free skies in China: the role of aerosols. Geophys Res Lett 34:L12804. doi:10.1029/2006GL028800

Qin SG, Shi GY, Chen L et al (2010) Long-term variation of aerosol optical depth in China based on meteorological horizontal visibility observations. Chin J Atmos Sci 34(2):449-456. doi:10.3878/jissn1006-989520100218 (in Chinese)

Ren GY, Zhou YQ (2014) Urbanization effects on trends of extreme temperature indices of national stations over mainland China, 1961-2008. J Clim 27(6):2340-2360

Ren GY, Xu MZ, Chu ZY, Chen ZH, Zhang AY, Guo J, Bai HZ, Liu XF (2005a) Changes of surface air temperature in China during 1951-2004. Clim Environ Res 10(4):717-727 (in Chinese)

Ren GY, Guo J, Xu MZ et al (2005b) Climate changes of mainland China over the past half century. Acta Meteorol Sin 63(6):942955 (in Chinese)

Ren GY, Zhou YQ, Chu ZY, Zhou JX, Zhang AY, Guo J, Liu XF (2008) Urbanization effects on observed surface air temperature trends in North China. J Clim 21:1333-1348. doi:10.1175/2007 JCLI13481

Ren GY, Ding YH, Zhao ZC, Zheng JY, Wu TW, Tang GL, Xu Y (2012) Recent progress in studies of climate change in China. Adv Atmos Sci 29(5):958-977

Shi GY, Hayasaka T, Ohmura A, Chen ZH, Wang B, Zhao JQ, Che HZ, Xu L (2008) Data quality assessment and the long-term trend of ground solar radiation in China. J Appl Meteorol Climatol 47:1006-1016. doi:10.1175/2007JAMC14931

Shi H, Xu JM, Li CC (2009) Analysis on variation and transition of surface solar radiation in south China. J Tropical Meteorol 25(2):209-215 
Stanhill G, Cohen S (2001) Global dimming: a review of the evidence for a widespread and significant reduction in global radiation with discussion of its probable causes and possible agricultural consequences. Agric For Meteorol 107:255-278. doi:10.1016/ S0168-1923(00)00241-0

Stern DI (2006) Reversal of the trend in global anthropogenic sulphur emissions. Global Environ Change 16:207-220

Stewart ID (2011) A systematic review and scientific critique of methodology in modern urban heat island literature. Int J Climatol 31:200-217. doi:10.1002/joc2141

Streets DG, Wu Y, Chin M (2006) Two-decadal aerosol trends as a likely explanation of the global dimming/brightening transition. Geophys Res Lett 33:L15806. doi:10.1029/2006GL026471

Trenberth KE, Jones PD, Ambenje P, Bojariu R, Easterling DR, Tank A, Parker D, Rahimzadeh F, Renwick JA, Rusticucci M, Soden B, Zhai P (2007) Observations: Surface and Atmospheric Climate Change Chapter 3 in Climate Change 2007: The Physical Science Basis Contribution of Working Group I to the Fourth Assessment Report of the Intergovernmental Panel on Climate Change. In: Solomon S, Qin D, Manning M, Chen Z, Marquis M, Averyt KB, Tignor M, Miller HL (eds) Met Office Hadley Centre contributors: L V Alexander, R J Allan, C K Folland, J J Kennedy and $\mathrm{P}$ W Thorne Cambridge University Press, Cambridge, New York, p 235-336

Vose RS, Easterling DR, Gleason B (2005) Maximum and minimum temperature trends for the globe: an update through 2004. Geophys Res Lett 32:L23822. doi:10.1029/2005GL024379

Wang K, Ye H, Chen F, Xiong Y, Wang C (2012) Urbanization effect on the diurnal temperature range: different roles under solar dimming and brightening. J Clim 25:1022-1027. doi:10.1175/ JCLI-D-10-050301

Wild M (2009) Global dimming and brightening: a review. J Geophys Res 114:D00-D16. doi:10.1029/2008JD01147

Wild M, Gilgen H, Roesch A, Ohmura A, Long CN, Dutton EG, Forgan B, Kallis A, Russak V, Tsvetkov A (2005) From dimming to brightening: decadal changes in surface solar radiation. Science 308:847-850. doi:10.1126/science 1103215

Wild M, Ohmura A, Makowski K (2007) Impact of global dimming and brightening on global warming. Geophys Res Lett 34:L04702. doi:10.1029/2006GL028031

Wu BY, Zhang RH (2007) Interdecadal shift in the Western North Pacific summer SST anomaly in the late 1980s. Chin Sci Bull 52:2559-2564

Wu BY, Yang K, Zhang RH (2009a) Eurasian snow cover variability and its association with summer rainfall in China. Adv Atmos Sci 26:31-44

Wu LR, Jiang ZH, Lu YP, Du JW, Qiao L (2009b) The calculation methods and distributive character of solar radiation in Shaanxi province. Scientia Meteorologica Sinica 29(2):187-191

Yan Z, Jones PD, Davies TD, Moberg A, Bergström H, Camuffo D, Cocheo C, Maugeri M, Demarée GR, Verhoeve T, Thoen E, Barriendos M, Rodríguez R, Martín-Vide J, Yang C (2002) Trends of extreme temperatures in Europe and China based on daily observations. Clim Change 53:355-392

You Q, Fraedrich K, Ren G, Pepin N, Kang S (2012) Variability of temperature in the Tibetan Plateau based on homogenized surface stations and reanalysis data. Int J Climatol 33:13371347. doi: $10.1002 /$ joc 3512

Zhai PM, Pan XH (2003) Trends in temperature extremes during 1951-1999 in China. Geophys Res Lett 30(17):1913-1916

Zhang R, Wu BY, Zhao P, Han JP (2008) The decadal shift of the summer climate in the late 1980s over Eastern China and its possible causes. Acta Meteorologica Sinica 22:435-445

Zhang AY, Ren GY, Zhou JX, Chu ZY, Ren YY, Tang GL (2010) Impacts of urbanization on trends of surface air temperature change in China. Acta Meteorologica Sinica 68(6):957-966 (in Chinese)

Zhang L, Ren GY, Liu J, Zhou YQ, Ren YY (2011a) Urbanization effect on trends of extreme temperature indices at Beijing Observatory. Chin J Geophys 54(5):1150-1159 (in Chinese)

Zhang XB, Alexander L, Hegerl GC, Jones P, Tank AK, Peterson TC, Trewin B, Zwiers FW (2011b) Indices for monitoring changes in extremes based on daily temperature and precipitation data. WIREs Clim Change. doi:10.1002/wcc147

Zhang XB, Zhou CX, Luo YX, Chen J, Zhao TL (2011c) Chinese province-level variations and trends in aerosol optical depth from recent 10 years of remote sensing data. Ecol Environ Sci 20(4):595-599 (in Chinese)

Zhang H, Wang Z, Wang Z, Liu Q, Gong S, Zhang X, Shen Z, Lu P, Wei X, Che H, Li L (2012) Simulation of direct radiative forcing of aerosols and their effects on East Asian climate using an interactive AGCM-aerosol coupled system. Clim Dyn 38:1675-1693. doi:10.1007/s00382-011-1131-0

Zhang RH, Wu BY, Han J, Zuo ZY (2013) Effects on summer monsoon and rainfall change over China due to Eurasian snow cover and ocean thermal conditions. In: Raj Singh B (ed) Climate change-realities, impacts over ice cap, sea level and risks. InTech, Rijeka, pp 227-250. doi:10.5772/54831

Zhou YQ, Ren GY (2009) The effect of urbanization on maximum, minimum temperature and daily temperature range in North China. Plateau Meteorol 28(5):1158-1166 (in Chinese)

Zhou YQ, Ren GY (2011) Change in extreme temperature events frequency over mainland China during 1961-2008. Clim Res 50(12):125-139. doi:10.3354/cr01053

Zhou LM, Dickinson RE, Tian YH, Fang JY, Li QX, Kaufmann RK, Tucker CJ, Myneni RB (2004) Evidence for a significant urbanization effect on climate in China. Proc Natl Acad Sci USA 101:9540-9544. doi:10.1073/pnas0400357101

Zhou J, Wu Y, Yan G (2005) General formula for estimation of monthly average daily global solar radiation in China. Energy Convers Manag 46(2):257-268

Zhou LM, Dickinson RE, Dai AG, Dirmeyer P (2010) Detection and attribution of anthropogenic forcing to diurnal temperature range changes from 1950 to 1999: comparing multi-model simulations with observations. Clim Dyn 35(7-8):1289-1307. doi:10.1007/ S00382-009-0644-2

Zuo ZY, Zhang RH, Huang Y, Xiao D, Guo D (2014) Extreme cold and warm events over China in wintertime. Int $\mathbf{J}$ Climatol. doi:10.1002/joc.4229 